\title{
NOVÝ VÝSKYT SKARNU V GFÖHLSKÉ JEDNOTCE U VEVČIC U JEVIŠOVIC: MINERÁLNÍ ASOCIACE SKARNU A KONTAMINOVANÝCH AMFIBOLICKÝCH PEGMATITŮ
}

\author{
A new occurrence of skarn in the Gföhl unit at Vevčice near Jevišovice: the mineral \\ assemblage of skarn and contaminated amphibole-bearing pegmatites \\ Stanislav Houzar', Jaroslav Šmerda ${ }^{2}$, David Buriánek ${ }^{3}$ \\ 'Mineralogicko-petrografické oddělení, Moravské zemské muzeum, Zelný trh 6, 65937 Brno; e-mail: shouzar@mzm.cz \\ 2 Jihomoravské muzeum ve Znojmě, Přemyslovců 8, 66945 Znojmo \\ ${ }^{3}$ Česká geologická služba, Leitnerova 22, 65859 Brno
}

(34-11 Znojmo)

Key words: garnet, pyroxene, potassian hastingsite, calcic skarn, mineral assemblage, amphibole-rich pegmatites, migmatization, Gföhl Unit, Moldanubian Zone

\begin{abstract}
This work provides detailed information about a new occurrence of skarn near Vevčice (near Jevišovice, western Moravia), which is one of the most important outcrops of these rocks in the southeastern part of the Moldanubian Zone (Gföhl Unit). The skarn is characterized by a strong migmatization, which resulted in contaminated amphibole pegmatite veins penetrating the skarn. The mineral assemblage of the skarn is simple, with dominant garnets, both grossular-almandine $\left(A \operatorname{lm}_{55-57} \operatorname{Grs}_{31-37} A_{d r_{3-8}}\right)$ and grossular-andradite-almandine $\left(\mathrm{Grs}_{45-53} A d r_{20-34} \mathrm{Alm}_{20-24}\right.$ ). Garnets clearly predominate over clinopyroxene, hedenbergite with a slightly increased "fassaite component". The very low amount of quartz contrasts with that in the skarns in the surrounding Gföhl unit. Amphibole (potassium-rich hastingsite) is younger mineral in the skarn, and especially in contaminated pegmatites. Epidote after garnets, and eventually prehnite, belong to the youngest minerals in some types of rocks. Accessory titanite, sometimes rich in Sn, was found frequently, as well as metamict REE-rich epidote. Magnetite is rather exceptional, mainly in assemblages replacing garnet; fluorapatite, ilmenite and zircon are rare. The studied skarn is part of a lithologically varied sequence of the Gföhl Unit, with intercalations of Ca-metasediments, appearing in several non-contiguous horizons around the boundary of so-called Běhařovice-Vémyslice synform, with a granulite-serpentinite complex in its center. This sequence of strongly migmatized biotite paragneiss to leucocratic migmatites also contains diopside and scapolite-diopside gneiss, garnet-pyroxene and phlogopite-diopside skarns containing magnetite and exceptionally $\mathrm{Au}-\mathrm{Co}-\mathrm{Bi}$ and REE mineralization as well as rare occurrences of spinel-forsterite dolomitic marbles.
\end{abstract}

\section{Úvod}

Skarny představují objemově málo významnou, ale typickou součást moldanubika na z. Moravě. V minulosti byly některé z nich zdrojem železné rudy, nejprve limonitu, vzniklého zvětráváním Ca-Fe silikátů, později i magnetitu. Pozornost byla věnována i mineralogii, petrologii a genezi těchto skarnů. Zatímco na převládající složení protolitu těchto hornin a tedy na podíl a rozsah metasomatických procesů při jejich vzniku nepanuje mezi badateli jednotný názor, shoda existuje v názoru na silné polymetamorfní přepracování těchto skarnů (srov. Němec 1991; Pertold et al. 2000; Pertoldová et al. 2009).

Výchozy skarnových hornin nejsou v krystaliniku z. Moravy př́liš časté a studiu nepř́stupná jsou v současnosti takřkka všechna důlní díla na místech historického dolování zmíněných skarnových železných rud.

$\mathrm{V}$ roce 2012 byl zjištěn jedním $z$ autorů (J. Š.) dosud neznámý výchoz skarnu u Vevčic, ležících $10 \mathrm{~km}$ na JV od Jevišovic, zajímavý jak svojí minerální asociací, tak zejména četnými injekčními proniky anatektických tavenin do skarnu a jejich Ca-Fe kontaminací. Z tohoto důvodu podáváme $\mathrm{v}$ prredkládané práci mineralogicko-petrografickou charakteristiku tohoto nového skarnového výskytu.

\section{Geografická pozice}

Širší oblast podél středního toku Jevišovky je součástí Znojemské pahorkatiny patřící k jv. okraji Českomorav- ské vrchoviny. Plochý a mírně zvlněný terén paroviny modelované předterciérní denudací porušují zaklesnutá údolí meandrujících vodních toků a do nich směřujících vodotečí s krátkými a strmými údolími.

Nový výskyt skarnu je součástí členitého skalního defilé na levém břehu Jevišovky asi $450 \mathrm{~m}$ na SV od silničního mostu vedoucího přes řeku ve Vevčicích (obr. 1). Lokalita je dostupná po polní cestě odbočující u mostu ze silnice. Řeka Jevišovka, přitékající ze SZ od Černína, zde prudce mění kolenovitým ohybem směr toku na JZ a boční erozí odkrývá v zalesněné stráni Na kopcích $(327 \mathrm{~m} \mathrm{n}$. m.) výchozy hornin. Rozsáhlejší skalní výchozy se skarnem lemují j. ústí rokle v místě, kde se napojuje do údolí Jevišovky ( $\left.48^{\circ} 57^{\prime} 45.120^{\prime \prime} \mathrm{N}, 16^{\circ} 3^{\prime} 7.050^{\prime \prime} \mathrm{E}\right)$. Ústí rokle lemují 3-8 m vysoké skalky, její dno vyplňuje rozvlečená bloková sut $\mathrm{z}$ rozpadajících se výchozů a materiál vyplavený $\mathrm{z}$ rokle.

\section{Geologická situace}

Zdejší oblast náleží gföhlské jednotce moldanubika. Jde o složitý komplex hornin spodnokorového (granulity) a pláštového původu (granátické a spinelové peridotity, eklogity) metamorfovaný v HT/HP podmínkách vyšší amfibolitové a granulitové facie (Dallmeyer et al. 1995; Medaris et al. 2013), s menším podílem suprakrustálních hornin (metapelity, mramory, částečně amfibolity). Pro gföhlskou jednotku je charakteristická velmi silná variská 


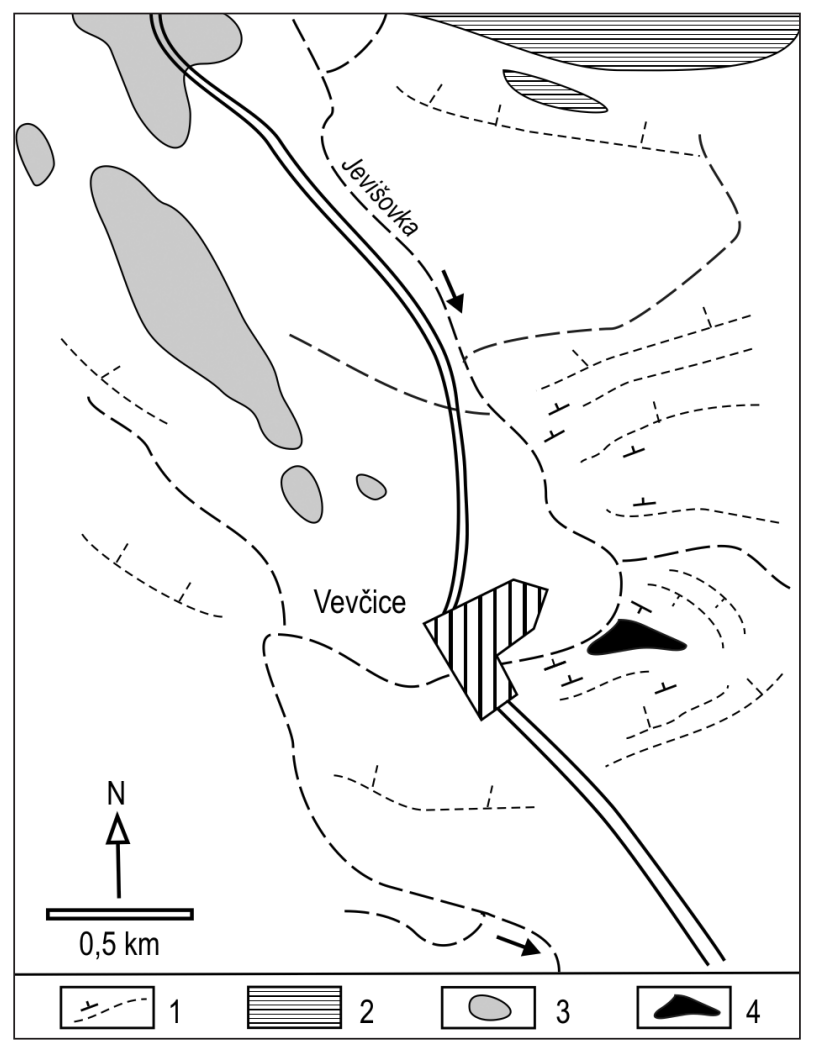

Obr. 1: Zjednodušená geologická mapa okolí studované lokality (upraveno podle Matějovské et al. 1987). Legenda: 1 - migmatitizovaná biotitická rula, 2 - amfibolit, 3 - serpentinit, eklogit, 4 - studovaný skarn.

Fig. 1: Simplified geological map of the area studied (modified by Matějovská et al. 1987). Explanation: migmatized biotite gneiss, 2 - amphibolite, 3 - serpentinite, eclogite, 4 - skarn studied (including amphibole pegmatites).

migmatitizace, která proběhla v několika fázích (Hasalová et al. 2008).

Ze starších autorů geologickou situaci a pozici horninových těles v oblasti řešil ve své geologické mapě např. Tomaschek (1933). Z hornin krystalinika přiznává největší rozsah biotitické rule, v údolí Jevišovky na $S$ od Vevčic popisuje těleso amfibolitu. Základní geologická mapa ČSSR $1: 25$ 000, list Višňové (Matějovská et al. 1987) uvádí v širší oblasti jako prostorově nejrozsáhlejší masivní leukokratní migmatit („gföhlská rula“), ve kterém jsou nepravidelně uzavírána tělesa migmatitizované biotitické pararuly s přechody do oftalmitického migmatitu, leukokratní mig matity s relikty granulitu, amfibolity, serpentinity, eklogity a pyroxenické ruly. Na místě výskytu skarnu je v této mapě uveden amfibolit.

Leukokratní migmatit, hornina s velmi proměnlivou texturou, je světle šedé až bělavé barvy. Je tvořená křemenem, živci a biotitem. Místy je v hornině až $3 \mathrm{~mm}$ velký granát a jehlicovitý sillimanit pokrývající spolu s biotitem plochy foliace. Vyšší intenzita migmatitizace se projevuje ztrátou paralelní stavby a přechodem ve světlejší masivní horninu charakteru aplitického granitu (někdy obsahuje turmalín). Migmatitizovaná biotitická pararula je středně zrnitá $s$ tmavě šedou barvou a s dobře vyvinutou břidlič natostí. Na mnoha místech v širším okolí Vevčic vystupují leukokratní migmatity s relikty rekrystalovaného granulitu.

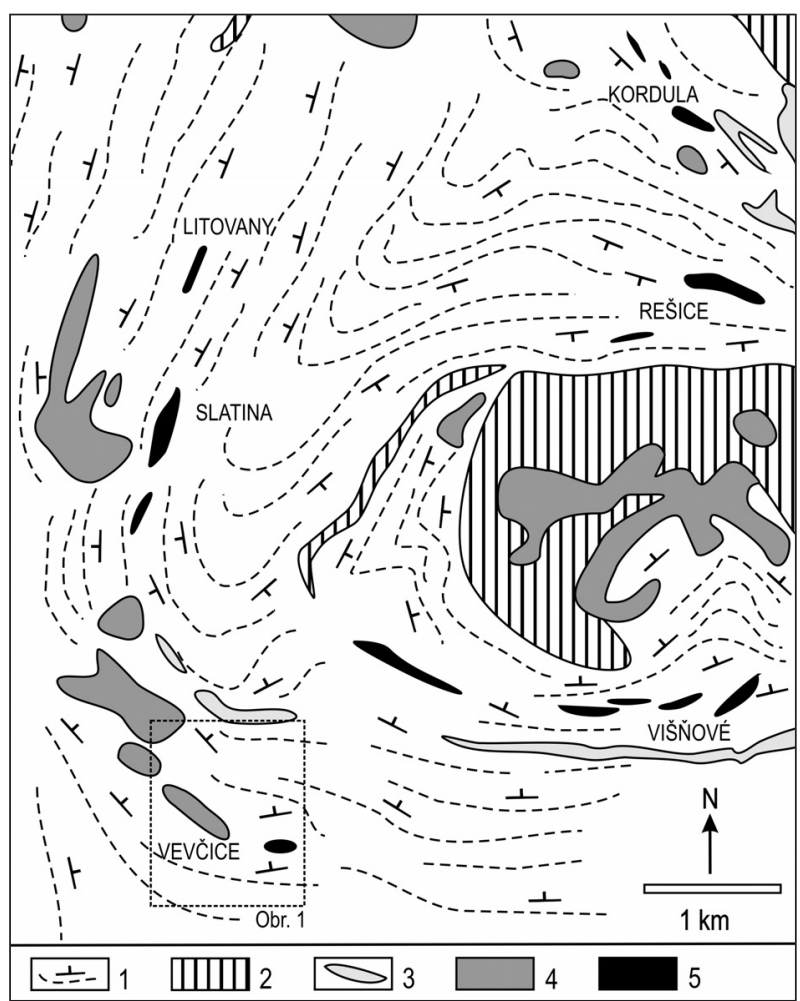

Obr. 2: Geologická pozice studovaného skarnu v rámci gföhlské jednotky na z. Moravě (upraveno podle Homoly 1960, Martince 1977 a Matějovské et al. 1987): 1 - leukokratní migmatit, 2 - granulit, převážně rekrystalizovaný, se sillimanitem, 3 - amfibolit, 4 - serpentinit, 5 - skarn a pyroxenická rula.

Fig. 2: Geological position of the skarn studied in Gföhl Unit of Western Moravia (modified according to Homola 1960, Martinec 1977 and Matějovská et al. 1987): 1 - leucocratic migmatite, 2 - sillimanite-bearing recrystalized granulite, 3 - amphibolite, 4 - serpentinite, 5 - skarn and pyroxene gneiss.

V okolí se nalézají rovněž amfibolity tvořící desítky až stovky metrů dlouhá protažená tělesa. Jsou tmavé, drobně zrnité s lavicovitou odlučností, kterou zvýrazňuje měnící se podíl živců v souvislosti s pokročilou migmatitizací. Ve světlém mobilizátu tvoří amfibol jen izolovaná zrna několik mm velká. $\mathrm{V}$ amfibolitu se také často vyskytuje granát vytvářející až $1 \mathrm{~cm}$ velká zrna nebo nepravidelné shluky velikosti až desítek cm, př́p. klinopyroxen; mezi akcesoriemi lze uvést titanit a zirkon. Pyroxenické ruly vystupují v širší oblasti jako malá čočkovitá tělesa sdružující se do sekvencí s určitou litostratigrafickou pozicí (obr. 2, Martinec 1977). Místy obsahují v podstatném množství skapolit (meionit). Východněji, u Višňového, byl zjištěn i granát-pyroxenický skarn s polohou Mg-skarnu (olivín-flogopit-amfibol) bohatou magnetitem, jehož množství přesahuje $50 \%$ (Němec 1963). Serpentinity tvoří malá, ale i stovky metrů velká tělesa na SSZ od Vevčic a hlavně dále u Černína. Obsahují až $5 \mathrm{~mm}$ velká masově červená zrna granátu s kelyfitickými lemy, klino- i ortopyroxeny a relikty olivínu. S nimi sdružené eklogity tvoří v rozsáhlejším okolí drobná tělesa uzavíraná v leukokratním migmatitu (Homola et al. 1968; Němec 1963; Matějovská et al. 1987). Širší strukturně-geologické postavení vevčického skarnu v gföhlské jednotce na z. Moravě vyplývá z geologické situace jeho s. okolí (obr. 2). Na mapě jsou též uvedena 
i ostatní tělesa skarnů (Kordula, Rešice, Litovany, Slatina a Višňové) a pyroxenických rul. Jen několik km odtud na J je tento moldanubický komplex nasunut na vranovskou jednotku tvořenou metapelity s vložkami metakarbonátů a kvarcitů, náležející podle současných převládajících názorů již k moraviku (Matějovská et al. 1987).

\section{Metodika}

Asociace minerálů byla studována v polarizovaném světle ve výbrusech, chemické složení minerálů bylo stanoveno na elektronové mikrosondě Cameca SX-100 ve vlnově disperzním módu v Laboratoři elektronové mikroskopie a mikroanalýzy, společném pracovišti Masarykovy univerzity a České geologické služby Brno (operátoři R. Škoda a P. Gadas). Minerály byly analyzovány při urychlovacím napětí $15 \mathrm{kV}$ při proudu svazku $10 \mathrm{a} 20 \mathrm{nA}$, průměr svazku 1 a $4 \mu \mathrm{m}$, podle jednotlivých druhů minerálů, za použití následujících standardů: $\mathrm{Si}, \mathrm{Al}, \mathrm{K}$ - sanidin, Si, Al, Mn spessartin, $\mathrm{Mn}-\mathrm{Mg}_{2} \mathrm{SiO}_{4}, \mathrm{Mg}$ - pyrop a spinel, $\mathrm{Na}$ - albit, $\mathrm{Ca}$ - wollastonit, $\mathrm{Ca}, \mathrm{Ti}$ - titanit, $\mathrm{Nb}$ - columbit (Ivigtut), $\mathrm{Ta}-\mathrm{CrTa}_{2} \mathrm{O}_{6}$, Ce, La, Pr, Nd, Sm, Gd, Dy, Er, Yb - příslušné fosfáty $\mathrm{Ce}, \mathrm{La}, \mathrm{Pr}$.....PO, $\mathrm{Cr}$ - chromit, $\mathrm{Cl}$ - vanadinit, $\mathrm{P}$ - fluorapatit, grossular (Ruda nad Moravou), Ca, $\mathrm{Si}$ - titanit (u titanitu), Fe - almandin, pyrop a hematit, $\mathrm{Ni}-\mathrm{Ni}_{2} \mathrm{SiO}_{4}, \mathrm{Sn}-\mathrm{Sn}, \mathrm{Th}$ - brabantit, $\mathrm{Sr}, \mathrm{S}-\mathrm{SrSO}_{4}, \mathrm{Sc}$, $\mathrm{V}-\mathrm{ScVO}_{4}, \mathrm{Ti}$ - anatas (Hardangervida), U - U, Y - $\mathrm{YPO}_{4}$, F - topaz, Ba - baryt, Zn - gahnit, Zr - zirkon. Všechny prvky byly načítány na linii Ka, hlavní 10-20 s, vedlejší 20-50 s. Naměřená data byla korigována automatickou PAP korekcí (Pouchou a Pichoir 1985).

\section{Charakteristika skarnu \\ Geologická pozice}

Studovaný skarn tvoří komplikované těleso, složené z několika texturních typů, silně prostoupené žílami amfibolických pegmatitů (obr. 3). Jeho maximální mocnost je asi $10 \mathrm{~m}, \mathrm{z}$ čehož přibližně necelá polovina objemu připadá na zmíněné pegmatity.

V bezprostředním okolí skarnu podle Matějovské et al. (1987) převládá migmatitizovaná biotitická rula. Je

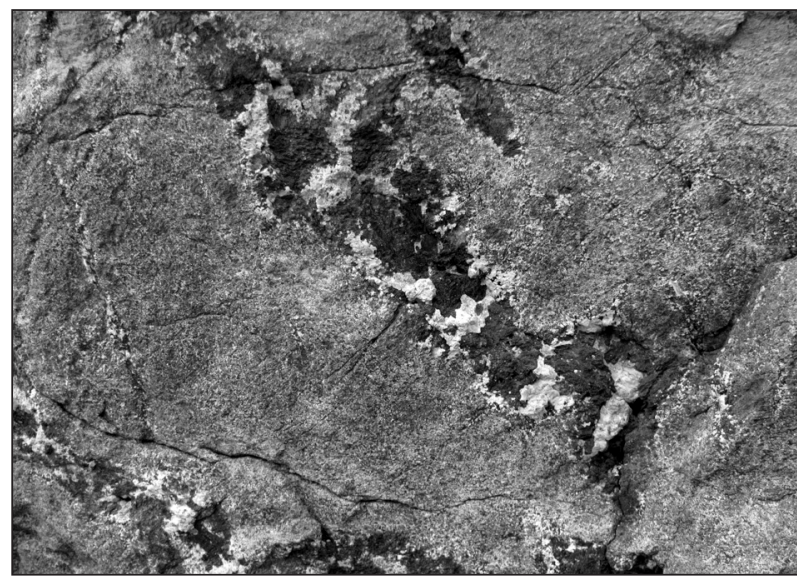

Obr. 3: Skarn s žilou kontaminovaného amfibolického pegmatitu o mocnosti $5 \mathrm{~cm}$ (foto J. Šmerda).

Fig. 3: Skarn with contaminated amphibole pegmatite vein with thickness $5 \mathrm{~cm}$ (photo by J. Šmerda). středně zrnitá s tmavě šedou barvou a s dobře vyvinutou foliací. Z tmavých minerálů dominuje drobně tabulkovitý biotit, tvořící místy také plošně provrásněné agregáty. Světlé partie jsou tvořeny živci a křemenem, dále je zastoupen granát (může často chybět) a sillimanit. $\mathrm{Z}$ akcesorických minerálů jsou př́tomny apatit, zirkon, magnetit a ilmenit. V těchto horninách se na SZ od skarnu vyskytují nehojná oválná tělesa (budiny?) vápenatosilikátových hornin velikosti $\leq 4 \mathrm{dm}$ (obr. 4). Ojediněle jsou zachovány relikty těchto hornin $s$ asociací anortit + diopsid \pm amfibol $\mathrm{s}$ akcesorickým červeným rutilem obrůstaným titanitem - většinou podlehly selektivnímu zvětrávání a ve výchozech na skalnatých stráních sz. od skarnu po nich zůstávají dutiny. Těsně při j. okraji skarnu vystupuje světlý rekrystalovaný granulit s granátem, reliktním kyanitem a mladším sillimanitem na plochách foliace. Na styku se skarnem je vyvinuta nevýrazná nehomogenní kontaktní zóna o mocnosti jen několika $\mathrm{cm} \mathrm{s}$ amfibolem, biotitem a granátem.

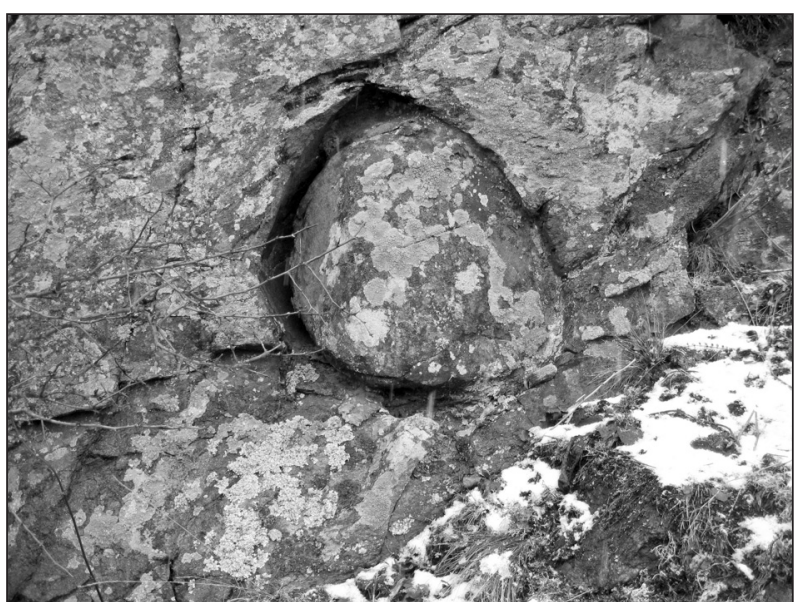

Obr. 4: Budina vápenatosilikátové horniny v gföhlské rule (foto J. Šmerda).

Fig. 4: Boudin of calc-silicate rocks in Gföhl gneiss (photo by J. Šmerda).

\section{Petrografie a minerální asociace}

Skarnové horniny jsou texturně i mineralogicky značně variabilní a jsou prostoupeny četnými žilkami amfibolických „pegmatitư “ rádově milimetrové až centimetrové mocnosti. Ty jsou vázány pouze na skarnové těleso a neobjevují se v okolních migmatitizovaných leukokratních rulách. Pouze na kontaktu těchto rul se skarnem byl ojediněle zjištěn amfibol-biotitový pegmatit s drobnými relikty skarnu. Ve výchozu lze sledovat přechody od převládajících skarnů obsahujících jen tenké žilky „pegmatitů“ až po amfibolické pegmatity, v nichž relikty skarnu tvoří max. $20 \%$ objemu. $\mathrm{V}$ tomto směru roste i obsah amfibolu ve skarnu, hranice skarnů a pegmatitů jsou ostré i přechodné.

Celkem bylo vymezeno 5 samostatných horninových typů: 1) pyroxen-granátický skarn; 2) amfibol-granátický skarn; 3) pyroxen-granátická vápenatosilikátová hornina s epidotem; 4) magnetit-pyroxen-amfibolický skarn s agregáty amfibolu a plagioklasu; 5) granát-amfibolický pegmatit s relikty drobnozrnného skarnu. 
1) Pyroxen-granátický skarn představuje převládající typ skarnu. Jde o středně zrnitou horninu se všesměrnou texturou a heteroblastickou strukturou, tmavě hnědočervené barvy, jen lokálně s podílem drobně zrnitého černého amfibolu. Ve výbrusu dominuje oranžově červený granát srůstající se světle zeleným hedenbergitem. Pyroxen je zatlačován amfibolem, který rovněž jako zřetelně mladší minerál proniká podél intergranulár zrnitým granátem. Zřetelně mladším minerálem je rovněž plagioklas, výjimečně i K-živec zatlačující společně s amfibolem (vzácně i symplektity plagioklas + amfibol) granát. Z akcesorických minerálů byl určen ojedinělý titanit, magnetit a zirkon.

2) Amfibol-granátický skarn je texturně i strukturně blízký předchozímu typu; je poněkud drobnějšího zrna a odlišuje se pouze podstatným množstvím drobně zrnitého až porfyroblastického amfibolu. Velké amfiboly (zrna $\mathrm{mm}-\mathrm{cm}$ velikosti) uzavírají granát, příp. granát zatlačovaný epidotem. Místy je ve skarnu zastoupen častěji plagioklas a klinopyroxen. Oproti předchozímu typu je hornina relativně bohatá magnetitem $\mathrm{v}$ asociaci s amfibolem + plagioklasem. Zrna magnetitu nepravidelně srůstají s ilmenitem (1,56 hm. \% MnO, MgO pod mezí stanovení) a jsou někdy lemovaná titanitem. Mohou obsahovat orientované „nitkovité“ inkluze Al-spinelidu.

3) Pyroxen-granátická vápenatosilikátová hornina s epidotem je drobnozrnná homeoblastická hornina s granoblastickou strukturou, tvořenou převažujícím granátem a lokálně i pyroxenem a epidotem. V mikroskopickém obrazu je charakteristický xenomorfně až laločnatě omezený, částečně reliktní granát zatlačovaný i uzavíraný drobně jehlicovitým epidotem několika generací, z nichž nejstarší epidot srůstá s granátem; vzácně i jako symplektity se složením granát + plagioklas + epidot. Nejmladší epidot tvoří výplně tenkých žilek a vějírovité agregáty v drobných dutinách zrn granátu, avšak v nich zřetelně převládá zejména prehnit. Z akcesorických minerálů dominuje titanit, někdy s podílem $S n$, místy také křemen a plagioklas.

4) Magnetit-pyroxen-amfibolický skarn s agregáty amfibolu a plagioklasu je černě zbarvená, jemnozrnná hornina s granoblastickou až nematogranoblastickou nestejnoměrně zrnitou strukturou, s hruběji zrnitými amfibol-plagioklasovými agregáty až žilkami. Dominujícími minerály jsou makroskopicky černé amfiboly (pleochroismus X-žlutozelená, Y-modrozelená, Z-khaki), obrůstající drobnější tmavozelené pyroxeny velikosti $<0,5 \mathrm{~mm}$. Amfibol, a někdy i klinopyroxen, má charakter poikiloblastů uzavírajících alterované živce, titanit a pyroxen. Magnetit je jemnozrnný a tvoří jen drobné agregáty max. milimetrové velikosti s pyroxenem a amfibolem. Je relativně bohatý $\mathrm{Ti}(0,022-0,087 \mathrm{apfu})$ a Al (0,044-0,066 apfu), chudý Mg, $\mathrm{Mn}, \mathrm{Cr}, \mathrm{Ni}, \mathrm{V}$ a Zn (vesměs při hranici stanovení). V některých partiích je zastoupen křemen a draselný živec, vzácnější je reliktní laločnatě omezený granát v plagioklasu, významnější akcesorii představuje pouze jehlicovitý apatit, ojedinělý je zirkon.

5) Granát-amfibolické pegmatity s relikty drobnozrnného skarnu jsou typickou horninou vevčického skarnu, jímž pronikají v nepravidelných žilách o mocnosti několika $\mathrm{cm}$ až několika dm. Obsahují četné uzavřeniny skarnu, s nímž mají ostré i rozplývavé kontakty. Na kontaktech nejsou obvykle vyvinuty žádné souvislé kontaktní lemy. Vystupují zejména při jz. okraji tělesa.

Nehledíme-li na skarnové uzavřeniny, je minerální asociace těchto žil jednoduchá. Jsou tvořeny z $95 \%$ středně zrnitými plagioklasy a vyrostlicemi černého amfibolu velikosti okolo $1 \mathrm{~cm}$. Převážně poikilitický amfibol uzavírá granát, jehož množství v některých př́ípadech vzrůstá až na několik \%. Pyroxeny zde, až na menší výjimky, chybějí, na rozdíl od jinak velmi podobných pegmatitů z okolních skarnových lokalit. Vzácný je tu také jinde běžný akcesorický titanit, místy hojněǰ̌́ je však epidot s vyšším obsahem REE. Pouze na kontaktu skarnu a rekrystalovaného granulitu je $\mathrm{v}$ asociaci s amfibolem, př́p. granátem, zastoupen chloritizovaný biotit a hlavně křemen.

Detailní charakteristice a genetickým vztahům kontaminovaných amfibolických pegmatitů a skarnu bude věnována podrobnější studie.

\section{Mineralogie \\ Granát}

Granát představuje převládající minerál skarnu, který se vyskytuje v několika minerálních asociacích. Hnědočervený středně zrnitý granát (typ I) v „granátovcích“ je sdružen převážně jak s plagioklasy, tak i s amfiboly. $\mathrm{V}$ prvním př́padě asociuje rovněž s pyroxenem (hedenbergitem), amfibol většinou granát uzavírá jako starší reliktní fázi. Ve stejných asociacích je zastoupen i v kontaminovaných pegmatitech, kde však jeho modální množství, až na výjimky (specifické granát-amfibolové pegmatity $z$ okraje skarnu) výrazně ustupuje do pozadí. Zřetelně reliktním minerálem je oranžově červený granát (typ II) v asociacích $s$ vápenatosilikátovou horninou, kde je často zatlačován epidotem a prehnitem (obr. 5).

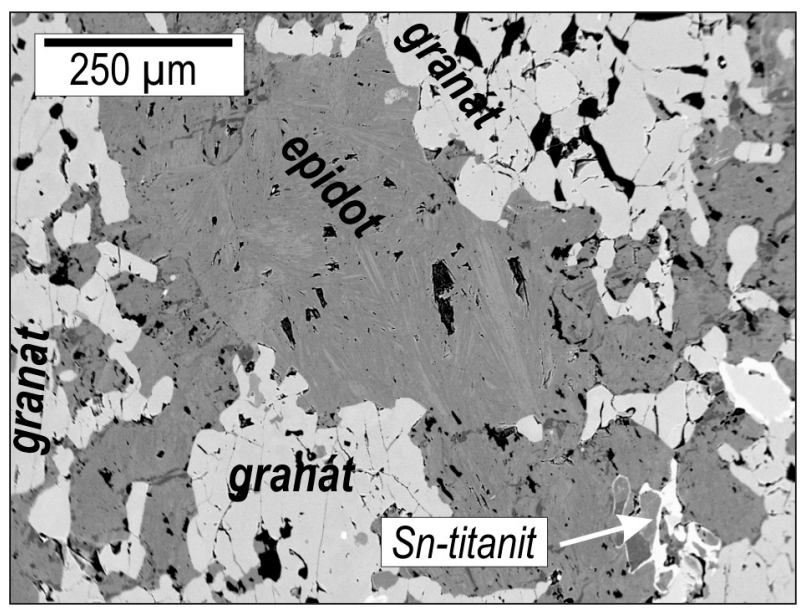

Obr. 5: Granát zatlačovaný jehlicovitým epidotem ve vápenatosilikátové hornině (odražené elektrony, foto P. Gadas).

Fig. 5: Garnet replaced by acicular epidote in calc-silicate rock (BSE, photo P. Gadas).

Chemické složení granátu odpovídá výše zmíněným dvěma hlavním typům. $\mathrm{V}$ asociaci s plagioklasy a amfiboly v granátu dominuje almandinová složka (55-57 mol. \% Alm) nad složkou grossularovou (31-37 mol. \% Grs) a andraditovou (3-8 mol. \% Adr), 
Tab. 1: Reprezentativní chemické analýzy granátů a pyroxenů.

Tab. 1: Representative chemical analyses of garnets and pyroxenes.

\begin{tabular}{|c|c|c|c|c|c|c|c|c|c|c|c|c|}
\hline & granát $1^{\star}$ & granát 2 & granát 3 & granát 4 & granát 5 & & pyroxen & pyroxen & pyroxen & pyroxen & pyroxen & pyroxen \\
\hline $\mathrm{SiO}_{2}$ & 37,93 & 38,10 & 37,96 & 37,36 & 38,02 & & 47,33 & 48,47 & 48,72 & 49,9 & 49,87 & 50,36 \\
\hline $\mathrm{TiO}_{2}$ & 0,14 & 0,08 & 0,16 & 0,38 & 0,22 & & 0,30 & 0,35 & 0,24 & 0,19 & 0,15 & 0,09 \\
\hline $\mathrm{Fe}_{2} \mathrm{O}_{3}$ & 2,41 & 0,94 & 2,68 & 11,32 & 6,74 & & 4,28 & 3,26 & 3,69 & 1,73 & 1,50 & 2,38 \\
\hline $\mathrm{FeO}$ & 25,67 & 25,28 & 25,08 & 8,72 & 10,82 & & 17,23 & 16,33 & 16,85 & 17,07 & 17,53 & 18,92 \\
\hline $\mathrm{MnO}$ & 0,61 & 0,60 & 0,34 & 0,22 & 0,13 & & 0,15 & 0,12 & 0,19 & 0,28 & 0,15 & 0,19 \\
\hline $\mathrm{CaO}$ & 13,07 & 13,98 & 13,68 & 27,69 & 26,12 & & 21,29 & 22,08 & 21,85 & 22,31 & 22,21 & 22,4 \\
\hline $\mathrm{Na}_{2} \mathrm{O}$ & 0,02 & 0,01 & b.d. & 0,01 & b.d. & & 0,46 & 0,35 & 0,63 & 0,40 & 0,38 & 0,33 \\
\hline Celkem & 100,96 & 100,81 & 101,00 & 99,62 & 99,87 & & 100,69 & 101,3 & 101,59 & 100,97 & 100,38 & 101,83 \\
\hline $\mathrm{Si}$ & 2,999 & 3,002 & 2,997 & 2,994 & 2,993 & & 1,853 & 1,872 & 1,883 & 1,931 & 1,944 & 1,952 \\
\hline $\mathrm{Ti}$ & 0,008 & 0,005 & 0,009 & 0,023 & 0,013 & & 0,009 & 0,010 & 0,007 & 0,006 & 0,004 & 0,003 \\
\hline $\mathrm{Fe}^{2+}$ & 1,698 & 1,666 & 1,656 & 0,584 & 0,712 & & 0,564 & 0,528 & 0,545 & 0,552 & 0,571 & 0,613 \\
\hline $\mathrm{Mn}$ & 0,041 & 0,040 & 0,023 & 0,015 & 0,009 & & 0,005 & 0,004 & 0,006 & 0,009 & 0,005 & 0,006 \\
\hline $\mathrm{Mg}$ & 0,156 & 0,117 & 0,171 & 0,037 & 0,082 & & 0,330 & 0,385 & 0,340 & 0,390 & 0,387 & 0,355 \\
\hline $\mathrm{Ca}$ & 1,107 & 1,180 & 1,157 & 2,377 & 2,203 & & 0,893 & 0,914 & 0,905 & 0,925 & 0,927 & 0,930 \\
\hline $\mathrm{Na}$ & 0,003 & 0,002 & & 0,002 & & & 0,035 & 0,026 & 0,047 & 0,030 & 0,029 & 0,025 \\
\hline Sum. kat. & 8 & 8 & 8 & 8 & 8 & & 4 & 4 & 4 & 4 & 4 & 4 \\
\hline $\mathrm{O}$ & 12 & 12 & 12 & 12 & 12 & & 6 & 6 & 6 & 6 & 6 & 6 \\
\hline Alm & 57 & 56 & 55 & 20 & 24 & & & & & & & \\
\hline Grs & 31 & 37 & 31 & 45 & 53 & & & & & & & \\
\hline Adr & 7 & 3 & 8 & 34 & 20 & $\mathrm{Al}_{\text {tot }}$ & 0,19 & 0,17 & 0,16 & 0,11 & 0,09 & 0,05 \\
\hline
\end{tabular}

* asociace granátu: 1 - symplektit granát+plagioklas, 2 - plagioklas+amfibol, 3 - pyroxen+plagioklas+magnetit, 4 - pyroxen+epidot (Ca-Si hornina), 5 - pyroxen+epidot (Ca-Si hornina)

* garnet assemblage: 1 - garnet+plagioclase symplectite, 2 - plagioclase+amphibole, 3 - pyxoxene+plagioclase+magnetite, 4 - pyroxene+epidote (Ca-Si rock), 5 - pyroxene+epidote (Ca-Si rock)

součet pyropové a spessartinové komponenty nepřevyšuje $6 \% \mathrm{~V}$ asociaci s mladším epidotem převládá grossularová složka ( $45-53$ mol. \% Grs) nad andraditovou (20-34 mol. \% Adr) a almandinovou (20-24 mol. \% Alm), nízký je podíl Prp a Sps (celkem < 3 mol. \%). Podíl Ti v obou typech je nízký, kolísá od 0,005 do 0,023 apfu), Na, $\mathrm{V}$ a Cr jsou na hranici detekce (tab. 1).

\section{Pyroxeny}

Tmavozelené pyroxeny s převažujícím podílem hedenbergitové složky (> 65 mol. \%) představují vzácnější vedlejší minerál vevčického skarnu, což vynikne zejména při porovnání s okolními skarny moldanubika. Kromě diopsidové komponenty $(0,330-0,390$ apfu Mg) se vyznačují převážně zvýšeným podílem "fassaitové složky“ $\left(\leq 0,185\right.$ apfu $\mathrm{Al}_{\text {to }} ; 0,044-0,126 \mathrm{Fe}^{3+} ; 0,025-0,047$ apfu Na; 0,003-0,010 Ti), Cr, V a Zn jsou pod mezí detekce (tab. 1).

\section{Amfiboly}

Amfibol tvoří ve skarnu drobné žilky a černozeleně zbarvené porfyroblasty vyznačující se silným pleochroismem a náleží ke zřetelně mladším minerálům. Proniká po intergranulárách mezi zrny granátu, který uzavírá a zatlačuje rovněž pyroxen. Podobný charakter má i amfibol (obr. 6) v asociaci s plagioklasem v pegmatitech, kde rovněž uzavírá drobná zrna granátu, jeho černá zrna však dosahují až několikacentimetrové velikosti.
Chemickým složením oba texturně-paragenetické typy amfibolu odpovídají draslíkem bohatému hastingsitu $\left(\leq 2,2 \mathrm{hm} . \% \mathrm{~K}_{2} \mathrm{O} ; \leq 1,8 \mathrm{hm} . \% \mathrm{Na}_{2} \mathrm{O} ; \mathrm{Mg} / \mathrm{Mg}+\mathrm{Fe}+\mathrm{Mn}\right.$ $=0,31-0,26$ ) a podobají se amfibolům $\mathrm{z}$ Vlastějovic (srov. Žáček 2007, Novák et al. 2013). Reprezentativní složení amfibolů je uvedeno v tabulce 2 a složení amfibolů $\mathrm{z}$ ten-

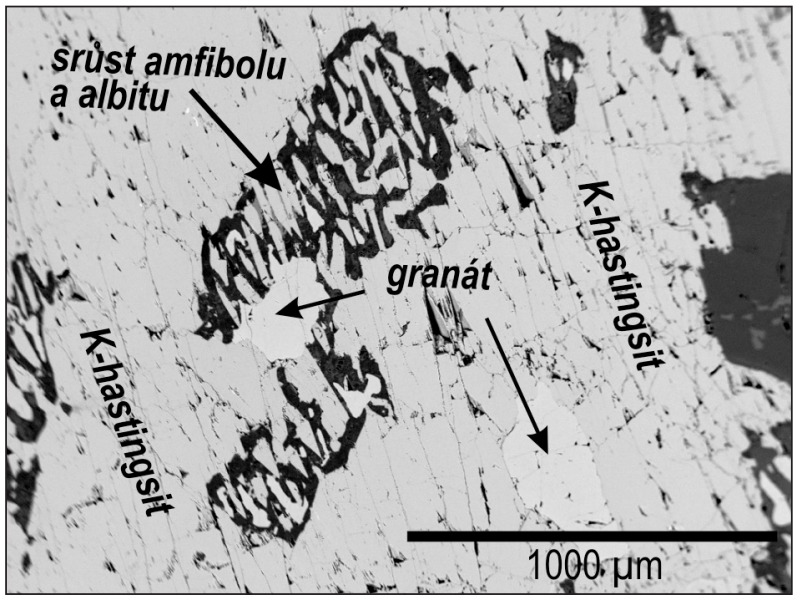

Obr. 6: Granát uzavíraný v porfyroblastu amfibolu (K-bohatý hastingsit) a srůsty amfibolu s albitem (odražené elektrony, foto P. Gadas).

Fig. 6: Garnet inclosed in amphibole (K-rich hastingsite) porphyroblast and amphibole intergrowths with albite (BSE, photo by P. Gadas). 
Tab. 2: Reprezentativní chemické analýzy amfibolů $\left(\mathrm{Fe}^{2+} / \mathrm{Fe}^{3+}\right.$ přpočteno metodou $13 \mathrm{eCNK}$ ).

Tab. 2: Representative chemical analyses of amphiboles $\left(\mathrm{Fe}^{2+} / \mathrm{Fe}^{3+}\right.$ calculation based on $13 \mathrm{eCNK}$ ).

\begin{tabular}{|c|c|c|c|c|c|}
\hline & hastingsit & hastingsit & hastingsit & hastingsit & hastingsit \\
\hline $\mathrm{SiO}_{2}$ & 38,92 & 37,78 & 38,72 & 39,14 & 40,15 \\
\hline $\mathrm{TiO}_{2}$ & 0,60 & 1,23 & 0,60 & 1,72 & 1,34 \\
\hline $\mathrm{Al}_{2} \mathrm{O}_{3}$ & 14,10 & 14,25 & 13,41 & 12,43 & 11,82 \\
\hline $\mathrm{FeO}$ & 20,29 & 19,49 & 19,88 & 21,68 & 19,37 \\
\hline $\mathrm{Fe}_{2} \mathrm{O}_{3}$ & 8,01 & 8,70 & 8,12 & 5,44 & 7,23 \\
\hline $\mathrm{MnO}$ & 0,19 & 0,13 & 0,08 & 0,17 & 0,04 \\
\hline $\mathrm{MgO}$ & 3,57 & 3,57 & 3,84 & 4,28 & 4,93 \\
\hline $\mathrm{CaO}$ & 11,52 & 11,21 & 11,12 & 11,59 & 11,31 \\
\hline $\mathrm{Na}_{2} \mathrm{O}$ & 1,21 & 1,32 & 1,67 & 1,44 & 1,76 \\
\hline $\mathrm{K}_{2} \mathrm{O}$ & 1,97 & 2,16 & 1,56 & 2,18 & 1,07 \\
\hline $\mathrm{H}_{2} \mathrm{O}$ & 1,96 & 1,95 & 1,94 & 1,95 & 1,95 \\
\hline $\mathrm{Cl}$ & 0,14 & 0,21 & 0,07 & 0,14 & 0,03 \\
\hline F & 0,31 & 0,38 & 0,27 & 0,33 & 0,41 \\
\hline $\mathrm{O}=\mathrm{F}+\mathrm{Cl}$ & $-0,16$ & $-0,21$ & $-0,13$ & $-0,17$ & $-0,18$ \\
\hline Celkem & 102,63 & 102,17 & 101,14 & 102,32 & 101,24 \\
\hline $\mathrm{Si}$ & 5,990 & 5,863 & 6,029 & 6,069 & 6,205 \\
\hline $\mathrm{Al}^{\mathrm{IV}}$ & 2,010 & 2,137 & 1,971 & 1,931 & 1,795 \\
\hline $\mathrm{Al}^{\mathrm{VI}}$ & 0,548 & 0,469 & 0,489 & 0,341 & 0,358 \\
\hline $\mathrm{Ti}$ & 0,069 & 0,144 & 0,070 & 0,201 & 0,156 \\
\hline $\mathrm{Fe}^{3+}$ & 0,928 & 1,016 & 0,951 & 0,635 & 0,841 \\
\hline $\mathrm{Fe}^{2+}$ & 2,612 & 2,529 & 2,588 & 2,812 & 2,503 \\
\hline $\mathrm{Mg}$ & 0,819 & 0,826 & 0,891 & 0,989 & 1,136 \\
\hline $\mathrm{Mn}$ & 0,025 & 0,017 & 0,011 & 0,022 & 0,005 \\
\hline $\mathrm{Ca}$ & 1,899 & 1,864 & 1,855 & 1,925 & 1,873 \\
\hline $\mathrm{Na}$ & 0,361 & 0,397 & 0,504 & 0,433 & 0,527 \\
\hline K & 0,387 & 0,428 & 0,310 & 0,431 & 0,211 \\
\hline $\mathrm{Cl}$ & 0,037 & 0,055 & 0,018 & 0,037 & 0,008 \\
\hline $\mathrm{F}$ & 0,151 & 0,186 & 0,133 & 0,162 & 0,200 \\
\hline Sum. kat. & 15,835 & 15,930 & 15,820 & 15,988 & 15,819 \\
\hline $\mathrm{O}$ & 23 & 23 & 23 & 23 & 23 \\
\hline
\end{tabular}

$\mathrm{Fe}_{2} \mathrm{O}_{3} ; \mathrm{FeO}$ rozpočteno podle stechiometrie

Tab. 3: Reprezentativní chemické analýzy živců.

Tab. 3: Representative chemical analyses of feldspars.

\begin{tabular}{|l|r|r|r|r|r|}
\hline & oligoklas & andesin & andesin & andesin & K-živec \\
\hline $\mathrm{SiO}_{2}$ & 64,86 & 60,75 & 57,76 & 57,40 & 64,75 \\
\hline $\mathrm{Al}_{2} \mathrm{O}_{3}$ & 22,73 & 25,36 & 26,57 & 27,04 & 18,57 \\
\hline $\mathrm{FeO}$ & 0,03 & 0,17 & 0,39 & 0,16 & 0,03 \\
\hline $\mathrm{CaO}$ & 3,82 & 7,08 & 8,94 & 9,33 & 0,02 \\
\hline $\mathrm{Na}_{2} \mathrm{O}$ & 9,18 & 7,50 & 6,75 & 6,47 & 1,05 \\
\hline $\mathrm{K}_{2} \mathrm{O}$ & 0,41 & 0,40 & 0,14 & 0,29 & 15,29 \\
\hline $\mathrm{Celkem}$ & 101,03 & 101,26 & 100,56 & 100,69 & 99,86 \\
\hline $\mathrm{Si}$ & 2,833 & 2,676 & 2,581 & 2,563 & 2,991 \\
\hline $\mathrm{Al}$ & 1,170 & 1,317 & 1,399 & 1,423 & 1,011 \\
\hline $\mathrm{Fe}{ }^{2+}$ & 0,001 & 0,006 & 0,015 & 0,006 & 0,001 \\
\hline $\mathrm{Ca}$ & 0,179 & 0,334 & 0,428 & 0,446 & 0,001 \\
\hline $\mathrm{Na}$ & 0,777 & 0,641 & 0,585 & 0,560 & 0,094 \\
\hline $\mathrm{K}$ & 0,023 & 0,022 & 0,008 & 0,017 & 0,901 \\
\hline $\mathrm{Sum}$. kat. & 4,983 & 4,997 & 5,016 & 5,014 & 5,001 \\
\hline $\mathrm{O}$ & 8 & 8 & 8 & 8 & 8 \\
\hline
\end{tabular}

K-živec obsahuje $0,15 \mathrm{hm} . \% \mathrm{BaO}$, celkové $\mathrm{Fe}$ jako $\mathrm{FeO}$ potassium feldspar contains 0.15 wt. \% $\mathrm{BaO}$, total $\mathrm{Fe}$ as a $\mathrm{FeO}$

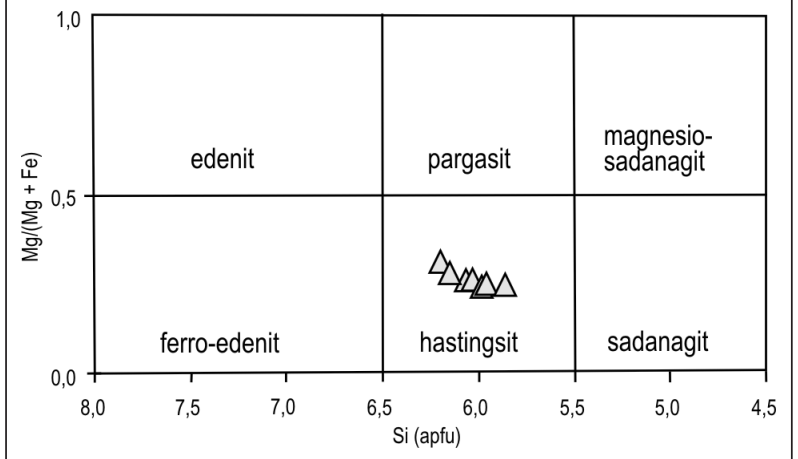

Obr. 7: Chemické složení amfibolu (Leake et al 1997) z kontaminovaných amfibolických pegmatitů.

Fig. 7: Chemical composition of amphiboles (Leake et al 1997) from contaminated amphibole-rich pegmatites.

kých pegmatoidních žil pronikajících skarnem je zřejmé z diagramu na obrázku 7 .

\section{Živce}

Převažujícími vedlejšími minerály jsou plagioklasy, které tvoří rovněž podstatnou součást pegmatitových žil. Jejich složení odpovídá většinou andezínu (0,3340,446 apfu Ca, 0,008-0,023 apfu K). Místy obsahují inkluze K-živce nepravidelného tvaru a lokálně jsou alterovány ve směs klinozoisitu a prehnitu (tab. 3). $\mathrm{V}$ pegmatitu je vzácnější K-živec běžného složení, s $\leq 0,15$ hm. \% BaO.

\section{Titanit}

Titanit je typickým a rozšířeným akcesorickým minerálem ve všech asociacích skarnu (obr. 8, tab. 4). Tvoří drobné mikroskopické krystaly, častěji však hypautomorfně až xenomorfně omezená zrna. Převažující objem zrn náleží titanitu s nízkým obsahem $\mathrm{Al}(\leq 0,121 \mathrm{apfu})$, $\mathrm{F}(\leq 0,105 \mathrm{apfu}), \mathrm{Fe}(\leq 0,046 \mathrm{apfu}), \mathrm{Sn}(\leq 0,012 \mathrm{apfu})$, $\mathrm{Na}(\leq 0,007 \mathrm{apfu})$ a $\mathrm{REE}\left(\leq 0,007 \mathrm{apfu} \mathrm{REE}_{\text {tot }}\right)$. Při okrajích je obrůstán nesouvislou úzkou zónou titanitu, který je bohatší na cín $\left(\leq 5,44 \mathrm{hm}\right.$. \% $\mathrm{SnO}_{2} ; \leq 0,072$ apfu Sn), $s$ mírně vyšším podílem $\mathrm{Al}(0,105-0,151 \mathrm{apfu})$ a $\mathrm{F}(0,094-$ $0,131 \mathrm{apfu})$.

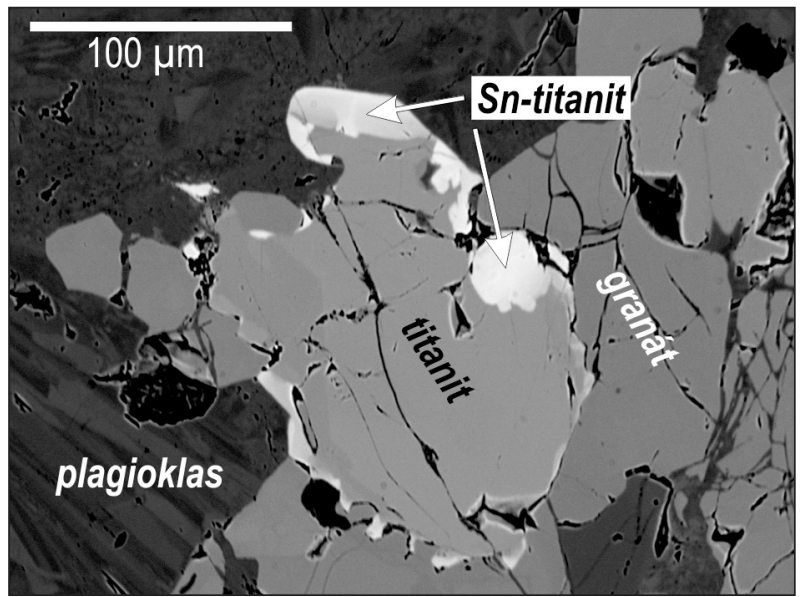

Obr. 8: Titanit, při okraji bohatý Sn, srůstající s granátem a plagioklasem (odražené elektrony, foto P. Gadas).

Fig. 8: Titanite, at the edge rich in Sn, intergrown with garnet and plagioclase (BSE, photo by P. Gadas). 
Tab. 4: Reprezentativní chemické analýzy titanitů a REE-epidotu. Tab. 4: Representative chemical analyses of titanites and REE-epidotes.

\begin{tabular}{|c|c|c|c|c|c|c|c|}
\hline & $\begin{array}{c}\text { REE- } \\
\text { epidot }\end{array}$ & $\begin{array}{c}\text { REE- } \\
\text { epidot }\end{array}$ & $\begin{array}{c}\text { Sn- } \\
\text { titanit }\end{array}$ & $\begin{array}{c}\text { Sn- } \\
\text { titanit }\end{array}$ & $\begin{array}{c}\text { Sn- } \\
\text { titanit }\end{array}$ & titanit & titanit \\
\hline $\mathrm{SiO}_{2}$ & 35,89 & 37,86 & 30,63 & 29,94 & 29,83 & 30,52 & 30,45 \\
\hline $\mathrm{TiO}_{2}$ & b.d. & 0,04 & 34,47 & 33,46 & 32,9 & 33,93 & 36,15 \\
\hline $\mathrm{ThO}_{2}$ & 0,62 & 0,56 & b. d. & b. d. & b. d. & b. d. & b. d. \\
\hline $\mathrm{SnO}_{2}$ & b. d. & b. d. & 1,09 & 1,45 & 5,44 & 0,92 & 0,58 \\
\hline $\mathrm{Nb}_{2} \mathrm{O}_{5}$ & b. d. & b. d. & 0,08 & 0,09 & 0,13 & 0,23 & 0,20 \\
\hline $\mathrm{Al}_{2} \mathrm{O}_{3}$ & 18,36 & 19,74 & 2,54 & 3,91 & 2,70 & 2,49 & 3,19 \\
\hline $\mathrm{Fe}_{2} \mathrm{O}_{3}$ & 11,27 & 10,28 & - & - & - & - & - \\
\hline $\mathrm{Ce}_{2} \mathrm{O}_{3}$ & 4,09 & 4,00 & 0,18 & 0,21 & 0,05 & 0,37 & 0,05 \\
\hline $\mathrm{La}_{2} \mathrm{O}_{3}$ & 2,60 & 2,34 & b. d. & b. d. & b. d. & b. d. & b. d. \\
\hline $\mathrm{Nd}_{2} \mathrm{O}_{3}$ & 2,01 & 1,89 & 0,11 & 0,14 & 0,03 & 0,27 & b. d. \\
\hline $\mathrm{Sm}_{2} \mathrm{O}_{3}$ & 0,22 & 0,12 & b. d. & b. d. & b. d. & b. d. & b. d. \\
\hline $\mathrm{Pr}_{2} \mathrm{O}_{3}$ & 0,61 & 0,53 & b. d. & b. d. & b. d. & b. d. & b. d. \\
\hline $\mathrm{Yb}_{2} \mathrm{O}_{3}$ & b.d. & 0,02 & b. d. & b. d. & b. d. & b. d. & b. d. \\
\hline $\mathrm{FeO}$ & - & - & 1,34 & 1,29 & 1,12 & 1,66 & 0,72 \\
\hline $\mathrm{CaO}$ & 14,25 & 14,47 & 27,98 & 27,87 & 27,91 & 27,73 & 28,82 \\
\hline $\mathrm{MnO}$ & 0,20 & 0,26 & b. d. & b. d. & b. d. & b. d. & b. d. \\
\hline $\mathrm{SrO}$ & 0,23 & 0,25 & b. d. & b. d. & b. d. & b. d. & b. d. \\
\hline $\mathrm{Na}_{2} \mathrm{O}$ & b. d. & b. d. & b. d. & 0,06 & 0,01 & b.d. & 0,11 \\
\hline $\mathrm{F}$ & b. d. & b. d. & 0,90 & 1,26 & 0,95 & 0,90 & 1,03 \\
\hline $\mathrm{O}=\mathrm{F}$ & & & $-0,38$ & $-0,53$ & $-0,40$ & $-0,38$ & $-0,43$ \\
\hline $\mathrm{H}_{2} \mathrm{O}^{*}$ & 1,66 & 1,72 & & & & & \\
\hline Celkem & 92,01 & 94,08 & 99,14 & 99,15 & 100,67 & 98,89 & 100,87 \\
\hline $\mathrm{Si}$ & 3,250 & 3,303 & 1,006 & 0,982 & 0,985 & 1,007 & 0,978 \\
\hline $\mathrm{Ti}$ & & 0,003 & 0,852 & 0,825 & 0,817 & 0,842 & 0,873 \\
\hline Th & 0,013 & 0,011 & & & & & \\
\hline Sn & & & 0,014 & 0,019 & 0,072 & 0,012 & 0,007 \\
\hline $\mathrm{Nb}$ & & & 0,001 & 0,001 & 0,002 & 0,003 & 0,003 \\
\hline $\mathrm{Al}$ & 1,960 & 2,030 & 0,098 & 0,151 & 0,105 & 0,097 & 0,121 \\
\hline $\mathrm{Fe}^{3+}$ & 0,768 & 0,675 & & & & & \\
\hline $\mathrm{Ce}$ & 0,136 & 0,128 & 0,002 & 0,003 & 0,001 & 0,004 & 0,001 \\
\hline $\mathrm{La}$ & 0,087 & 0,075 & & & & & \\
\hline $\mathrm{Nd}$ & 0,065 & 0,059 & 0,001 & 0,002 & & 0,003 & \\
\hline $\mathrm{Sm}$ & 0,007 & 0,004 & & & & & \\
\hline $\operatorname{Pr}$ & 0,020 & 0,017 & & & & & \\
\hline $\mathrm{Yb}$ & & 0,001 & & & & & \\
\hline $\mathrm{Fe}$ & & & 0,037 & 0,035 & 0,031 & 0,046 & 0,019 \\
\hline $\mathrm{Ca}$ & 1,383 & 1,353 & 0,985 & 0,979 & 0,987 & 0,981 & 0,992 \\
\hline $\mathrm{Mn}$ & 0,015 & 0,019 & & & & & \\
\hline $\mathrm{Sr}$ & 0,012 & 0,013 & & & & & \\
\hline $\mathrm{Na}$ & & & & 0,004 & 0,001 & & 0,007 \\
\hline $\mathrm{F}$ & & & 0,094 & 0,131 & 0,099 & 0,094 & 0,105 \\
\hline Sum. kat. & 7,716 & 7,689 & 3 & 3 & 3 & 3 & 3 \\
\hline $\mathrm{O}$ & 13 & 13 & 4,880 & 4,838 & 4,879 & 4,874 & 4,867 \\
\hline Sum. an. & & & 4,973 & 4,968 & 4,978 & 4,968 & 4,972 \\
\hline
\end{tabular}

\section{Epidot}

Minerály epidotové skupiny jsou běžné ve všech minerálních asociacích, nikde však nedosahují většího množství a jejich velikost je až na výjimky pouze mikroskopická. Jsou zastoupeny dvěma, chemicky výrazně odlišnými typy (tab. 4 a 5).

V prvním př́ípadě jde o izometrická zrna silně metamiktně přeměněného a nehomogenního epidotu
(0,675-0,768 apfu Fe; 0,015-0,019 apfu Mn; 0,012-0,013 apfu Sr) se zvýšeným obsahem REE (zejména 0,128-0,136 apfu Ce; 0,075-0,075 apfu La a 0,059-0,065 apfu Nd) $\mathrm{v}$ asociaci s amfibolem a plagioklasy (obr. 9).

Druhý typ je drobně jehličkovitý klinozoisit až epidot (0,025-0,758 apfu Fe; <0,003 apfu Mn, SrO a REE na hranici stanovení), zatlačující granát a plagioklas ve vápenatosilikátové hornině, příp. vyplňující drobné dutiny skarnu nebo je společně s prehnitem vyvinut jako výplň mikrotrhlin.

\section{Závěr}

Nově zjištěný skarn u Vevčic představuje jeden $\mathrm{z}$ mála výchozů skarnů $\mathrm{v}$ této části moldanubika. Minerální asociace skarnu je jednoduchá, s granátem o převažujícím složení grossular-almandin, lokálně s vyšším

Tab. 5: Reprezentativní chemické analýzy epidotu a prehnitu. Tab. 5: Representative chemical analyses of epidote and prehnite.

\begin{tabular}{|l|r|r|r|r|}
\hline & \multicolumn{1}{|c|}{$\begin{array}{c}20 \\
\text { epidot }\end{array}$} & $\begin{array}{c}15 \\
\text { epidot }\end{array}$ & $\begin{array}{c}\text { 24 } \\
\text { klinozoisit }\end{array}$ & \multicolumn{1}{c|}{$\begin{array}{c}17 \\
\text { prehnit }\end{array}$} \\
\hline $\mathrm{SiO}_{2}$ & 38 & 38,57 & 39,40 & 43,24 \\
\hline $\mathrm{Al}_{2} \mathrm{O}_{3}$ & 23,67 & 26,41 & 33,30 & 21,98 \\
\hline $\mathrm{Fe}_{2} \mathrm{O}_{3}$ & 12,73 & 9,77 & 0,44 & 3,30 \\
\hline $\mathrm{CaO}$ & 23,68 & 23,83 & 24,46 & 27,12 \\
\hline $\mathrm{MnO}$ & 0,04 & 0,01 & b. d. & 0,02 \\
\hline $\mathrm{H}_{2} \mathrm{O}^{*}$ & 1,89 & 1,92 & 1,97 & 4,31 \\
\hline $\mathrm{Celkem}$ & 100,37 & 100,51 & 99,57 & 99,97 \\
\hline $\mathrm{Si}$ & 3,009 & 3,006 & 2,996 & 3,008 \\
\hline $\mathrm{Al}$ & 2,209 & 2,426 & 2,985 & 1,802 \\
\hline $\mathrm{Fe}{ }^{3+}$ & 0,758 & 0,573 & 0,025 & 0,173 \\
\hline $\mathrm{Ca}$ & 2,009 & 1,990 & 1,993 & 2,021 \\
\hline $\mathrm{Mn}$ & 0,003 & 0,001 & & 0,001 \\
\hline $\mathrm{H}$ & 1 & 1 & & 2 \\
\hline $\mathrm{CatSum}$ & 8,001 & 7,995 & 7,999 & 7,005 \\
\hline $\mathrm{O}$ & 13 & 13 & 13 & 12 \\
\hline
\end{tabular}

* dopočteno ze stechiometrie; determined by stoichiometry b. d. pod mezí stanovení; below detection limits: $\mathrm{TiO}_{2}, \mathrm{ThO}_{2}, \mathrm{Y}_{2} \mathrm{O}_{3}, \mathrm{Ce}_{2} \mathrm{O}_{3}$, $\mathrm{La}_{2} \mathrm{O}_{3}, \mathrm{Nd}_{2} \mathrm{O}_{3}, \mathrm{Sm}_{2} \mathrm{O}_{3}, \mathrm{Pr}_{2} \mathrm{O}_{3}, \mathrm{Yb}_{2} \mathrm{O}_{3}$ vz. 20 obsahuje $0,08 \mathrm{hm} . \% \mathrm{SrO}$, sample 20 contains 0.08 wt. $\%$ SrO

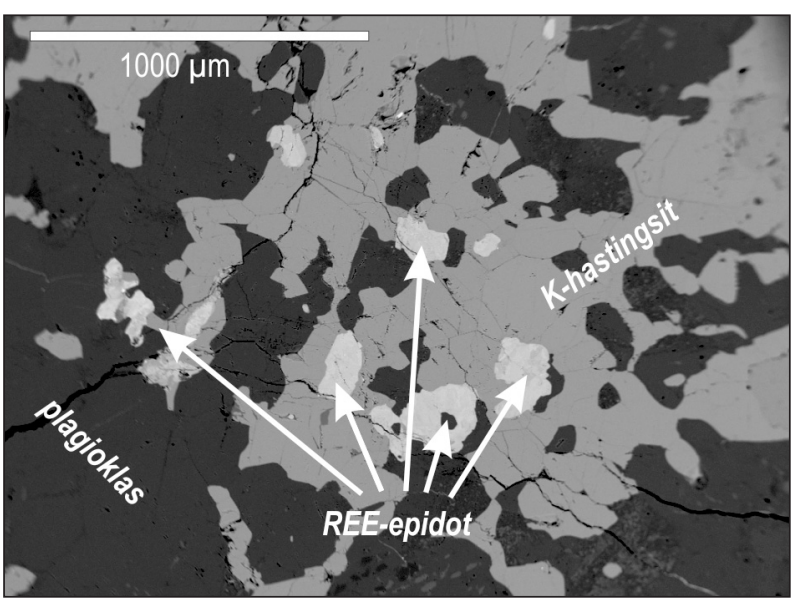

Obr. 9: Zrna REE-bohatého epidotu v amfibolu (odražené elektrony, foto P. Gadas).

Fig. 9: REE-rich epidote grains in amphibole (BSE, photo by P. Gadas). 
obsahem andraditové složky, převládajícím výrazně nad hedenbergitem (s mírně zvýšeným podílem „fassaitové komponenty“). Zřetelně mladším minerálem je amfibol, zastoupený ve skarnech i v kontaminovaných pegmatitech K-bohatým hastingsitem, doprovázený plagioklasy a ojediněle také K-živcem. V některých typech skarnu náleží k nejmladším minerálům žlutozelený epidot, příp. prehnit, vyplňující intergranuláry a drobné dutinky v granátické vápenatosilikátové horninè. Za zmínku stojí také nízký podíl křemene, jenž je tu na rozdíl od jiných skarnů a skarnoidů gföhlské jednotky jen akcesorickým minerálem. Z dalších akcesorických minerálů byl zjištěn titanit, místy s vyšším zastoupením Sn a REE-bohatý epidot, naopak magnetit je spíše výjimečný hlavně $\mathrm{v}$ amfibol-pyroxenických asociacích (bez granátu); podobně vzácné jsou fluorapatit, ilmenit a zirkon.

V porovnání se skarnem, uloženým v kyanit-granátickém granulitu na Kleti (Vrána 1987), vykazuje vevčický skarn vedle značně vysokého poměru granát/pyroxen zejména hojný granát dvou typů (almandin-grossular a andradit-grosssular-almandin), častý K-bohatý amfibol (hastingsit); typická je zde rovněž nepř́tomnost skapolitu a podstatného podílu magnetitu a rovněž v průměru nižší podíl „fassaitové složky“ a více železa v klinopyroxenu. Ve srovnání s okolními skarny (Slatina, Litovany, Rešice, Kordula, Višňové) tu chybějí vedle podstatného podílu $\mathrm{Na} v$ klinopyroxenech (Pertold et al. 2000) zejména magnetitové Mg-skarny, jinak velmi typické pro tuto část gföhlské jednotky.

Vevčický skarn je charakteristický projevy migmatitizace, při níž vznikly žíly primitivních amfibolických anatektických hornin charakteru nezonálních pegmatitů. Pronikají nepravidelně celým tělesem skarnu, místy nad skarnem dokonce objemově převládají. Tyto kontaminované pegmatity však nedosáhly tak pokročilé diferenciace a frakcionace jako např. amfibolové pegmatity s křemenem, allanitem, fluoritem a Al, F-titanitem ve skarnech u Vlastějovic (Novák et al. 2013).

Studovaný skarn je součástí silně migmatitizované, litologicky pestré sekvence s podílem Ca-metasedimentů v gföhlských rulách, vystupující v několika nesouvislých horizontech po obvodu tzv. běhařovicko-vémyslické synformy, mající ve svém centru peridotit-granulitový komplex. K této sekvenci, význačné převahou migmatitizovaných biotitických pararul až leukokratních migmatitů, náležejí převážně diopsidové a skapolit-diopsidové ruly (Homola et al. 1968; Martinec 1977), granát-pyroxenické a flogopit-diopsidické Mg-skarny zrudněné magnetitem, výjimečně s akcesorickou $\mathrm{Au}-\mathrm{Co}-\mathrm{Bi}$ a REE-mineralizací a vzácně i dolomitické, spinel-forsteritové mramory (Němec 1960, 1963). Ke skarnovým výskytům v této oblasti náležejí lokality Kordula (Němec 1960), Rešice-Valův mlýn u Rouchovan (Pertold et al. 2000; Filip et al. 2002; Malec et al. 2013), dále Višňové (Němec 1963), Slatina-Na Roudnici (Pertold et al. 2000), Litovany-Újezdský mlýn (Houzar a Šrein 1999), Vevčice (tato práce) a několik dalších nepatrných výskytů charakteru budin o velikosti jen okolo $1 \mathrm{~m}$. Přestože není důvod přiřazovat těmto skarnům a vápenatosilikátovým horninám určitou litostratigrafickou pozici, je jejich prostorová asociace se spodně korovými (granulity) a pláštovými horninami (granátické peridotity a eklogity) zřejmá.

Ojedinělé relikty metakarbonátových hornin (dolomitických mramorů) sdružených se skarny, zejména při s. okraji této sekvence, dokládají jak přítomnost svrchnokorových sedimentárních hornin ve gföhlské jednotce, tak rovněž umožňují uvažovat i o jejich možném podílu na genezi skarnů (srov. Němec 1991). Lokalita Vevčice však neposkytuje o účasti metakarbonátového protolitu na genezi zdejšího skarnu žádné doklady.

\section{Poděkování}

Předložená práce vznikla za finanční podpory Ministerstva kultury v rámci institucionálního financování na dlouhodobý koncepční rozvoj výzkumné organizace Moravské zemské muzeum (DKRVO, MK000094862) a projektu ČGS 321180 (Základnígeologické mapování v měř́tku 1 : 25 000). Autoři děkují S. Vránovi a anonymnímu recenzentovi za kritické pročtení rukopisu. 
Literatura

Dallmeyer, R. D. - Franke, W. - Weber, K. (1995): Pre-Permian Geology of Central and Eastern Europe. (Chapter VII. Moldanubian Zone). - Springer Verlag, Berlin - Heidelberg, 317-466.

Filip, J. - Houzar, S. - Sulovský, P. (2002): Allanit a produkty jeho přeměny ve skarnu a pegmatitu z Rešic. - Acta Musei Moraviae, Scientiae geologicae, 87, 87-101.

Hasalová, P. - Janoušek, V. - Schulmann, K. - Štípská, P. - Erban, V. (2008): From orthogneiss to migmatite: Geochemical assessment of the melt infiltration model in the Gföhl Unit (Moldanubian Zone, Bohemian Massif). - Lithos, $102,508-537$.

Homola, V. - Muller, K. - Smrkovská, V. (1968): Geologisch-geophysikalische Studien im Gebiet des westmährischen Moldanubikums. - Freiberger Forschungshefte, C 227, 1-71.

Houzar, S. - Šrein, V. (1999): Puklinová mineralizace skarnu u Litovan, západní Morava. - Přírodovědný sborník Západomoravského muzea v Třebíči, 39, 1-6.

Leake, B. E. - Woolley, A. R. - Arps, C. E. S. - Birch, W. D. - Gilbert, M. C. - Grice, J. D. - Hawthorne, F. C. - Kato, A. - Kisch, H. J. - Krivovichev, V. G. - Linthout, K. - Laird, J. - Mandarino, J. - Maresch, W. V. - Nickel, E. H. - Rock, N. M. S. - Schumacher, J. C. - Smith, D. C. - Stephenson, N. C. N. - Ungaretti, L. - Whittaker, E. J. W. - Youzhi, G. (1997): Nomenclature of amphiboles: Report of the subcommittee on amphiboles of the international mineralogical association commission on new minerals and mineral names. - Mineralogical Magazine, 61, 2, 295-321.

Malec, J. - Veselovský, F. - Táborský, Z. (2013): Parageneze a sukcese rudních minerálů ve vybraných skarnech Českomoravské vrchoviny. - Acta Musei Moraviae, Scientiae geologicae, 98, 1, 13-22.

Martinec, P. (1977): Erlany a skarny v komplexu tzv. gföhlských rul v moldanubiku jz. Moravy. - In: Pouba, Z. (ed.): „Korelace proterozoických a paleozoických stratiformních ložisek V.“, Ústav geol. Věd, Přírod. fak. UK, Praha, 163-182.

Matějovská, O. - Batík, P. - Dornič, J. - Havlíček, P. - Hazdrová, M. - Jenček, V. - Kadlec, E. - Líbalová, J. - Šalanský, K. - Volšan, V. (1987): Vysvětlivky k základní geologické mapě ČSSR 1 : 25 000, list 34-111 Višňové. - Ústř. úst. geol. Praha. 54 s.

Medaris, G. L., jr. - Jelínek, E. - Beard, B. L. - Valley, J. W. - Spicuzza, M. J. - Strnad, L. (2013): Garnet pyroxenite in the Biskupice peridotite, Bohemian Massif: anatomy of a Variscan high-pressure cumulate. - Journal of Geosciences, 58, 3-19.

Němec, D. (1960): Poznámky ke skarnům v okolí Korduly u Rouchovan. - Časopis Moravského muzea, Vědy př́rodní, 45, 37-44.

Němec, D. (1963): Mg-Skarne des westmährischen Kristallins. - Sitzungsberichten Österreichises Akademie der Wissenschaften, Mathem.- naturw. Kl., Abt. I, N. 172, 263-308

Němec, D. (1991): Regional typization of the iron skarns of the Bohemian - Moravian heights. - Acta Musei Moraviae, Scientiae naturales, 76, 51-82.

Novák, M. - Kadlec, T. - Gadas, P. (2013): Geological position, mineral assemblages and contamination of granitic pegmatites in the Moldanubian Zone, Czech Republic; examples from the Vlastějovice region. - Journal of Geosciences, 58, 1, 21-47.

Pertold, Z. - Pertoldová, J. - Pudilová, M. (2000): Metamorphic history of skarn in the Gföhl Unit, Moldanubicum, Bohemian Massif, and implication for their origin. - Acta Universitas Carolinae, Geologica, 41, 157-166.

Pertoldová, J. - Týcová, R. - Verner, K. - Košuličová, M. - Pertold, Z. - Košler, J. - Konopásek, J. - Pudilová, M. (2009): Metamorphic history of skarns, origin of their protolith and implications for genetic interpretation; an example from three units of the Bohemian Massif. - Journal of Geosciences, 54, 101-134.

Pouchou, J. L. - Pichoir, F. (1985): “PAP” procedure for improved quantitative microanalysis. - Microbeam Analysis, 20, 104-105

Tomaschek, O. (1933): Die geologischen Verhältnisse des polit. Bezirkes Znaim. II. Teil Znaimer Bezirk. - Znaim, $25 \mathrm{~s}$.

Vrána, S. (1987): Garnet-fassaitic pyroxene skarn from the granulite complex of southern Bohemia. - Věstník Ústředního ústavu geologického, 62, 4, 193-206.

Žáček, V. (2007): Potassian hastingsite and potassichastingsite from garnet-hedenbergite skarn at Vlastějovice, Czech Republic. - Neues Jahrbuch für Mineralogie - Abhandlungen, 184, 2, 161-168. 